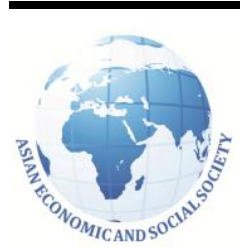

AESS
Journal of Asian Business Strategy

http://www.aessweb.com/journals/5006

DOI: $10.18488 /$ journal.1006/2015.5.7/1006.7.141.152

\title{
ADVERTISING AND COUNTRY OF ORIGIN AS KEY SUCCESS FACTORS FOR CREATING SUSTAINABLE BRAND EQUITY
}

\author{
Jalal Hanaysha \\ Doctoral Scholar; College of Business, Universiti Utara Malaysia, Sintok, Malaysia \\ Haim Hilman \\ Associate Professor; College of Business, Universiti Utara Malaysia, Sintok, Malaysia
}

\section{Article History:}

Received: 1 June 2015

Revised received: 3

July 2015

Accepted: 29 July

2015

Online available: 3

August 2015

Keywords:

Advertising,

brand equity,

country of origin

\begin{abstract}
Today's markets have become highly competitive and challenging, therefore, a careful understanding of the key success factors that may help firms to sustain their brands is very important. In past literatures, it is evident that consumers prefer to purchase brands that provide them with unique values and differentiated features. However, this study focuses on advertising and country of origin effects as key success factors for building sustainable brand equity, because they were found to be important in influencing consumer behaviour. To explore our knowledge in this area, Malaysian automotive industry was selected. The data were collected from a total of 287 passenger cars owners through survey questionnaire at shopping malls in the northern region of Malaysia. The findings revealed that advertising and country of origin had significant positive effects on overall brand equity. Moreover, this study found that advertising and country of origin had significant positive effects on the dimensions of brand equity, namely; brand loyalty, brand image, brand awareness, and brand leadership. Based on the findings of this study, some implications have been highlighted to enhance our knowledge on the importance of the selected factors in building strong brand equity.
\end{abstract}

\section{INTRODUCTION}

Branding issues have turned to be the foremost important concern for many organizations. This is because a successful brand provides the firm with opportunities to utilize its core competences and differentiated organizational structure to secure a position in consumers' minds (Keller, 1993). The term brand can be described as a name, sign, symbol or any attributes which can differentiate one manufacturer's products and services from other competing organizations (Bennett, 1995). The brand provides customers with functional and emotional features that can influence their satisfaction and purchase decisions (Hankinson \& Cowking, 1996). Mutsikiwa et al. (2013) revealed that building

Corresponding author's

Name: Jalal Hanaysha

Email address: jalal.hanayshi@yahoo.com 
strong brand image has been the main driver for business success in highly competitive market environments.

One of the key concepts in branding is brand equity. Brand equity encompasses customer's attitude toward various marketing activities. It reflects the intangible features attached to the products through brand name. In fact, creating brand equity is considered a significant part of brand establishment (Takali et al., 2012). Recently, the focus on brand equity research has been growing. One of the main reasons for its popularity is due to its strategic role in helping firms to obtain sustainable competitive advantage and make better decisions. The management of brand equity is very essential for assessing the long-term effect of marketing actions (Keller, 2003). Particularly, brand equity is a valuable intangible asset that can endow companies with various competitive advantages. However, in order to manage this intangible asset, it is vital develop a careful understanding of its contributing factors (Bilkey \& Nes, 1982).

In business markets which are characterized by intensity of competition among various organizations, it has become very important for marketers to look for appropriate branding strategies that could guide them to maintain their customers by providing superior customer value. Extant research indicates that marketing activities could affect the creation of brand equity. For instance, country of origin has been regarded as in important factor that affects customers' overall evaluations of brands. Saydan (2013) emphasized on the importance of country of origin in influencing consumers' perceptions of brands and suggested for future researches to examine its effect on brand equity. Advertising is another important variable that could influence customers' perceptions of brands. Ardestani et al. (2014) recommended studying the impact of advertising on brand equity in an attempt to gain better understandings on the dimensions of brand equity.

In past literature, brand equity has been measured using a set of dimensions and the majority of researchers have focused on four key dimensions (perceived quality, brand association, brand loyalty, and brand awareness) that were proposed by Aaker (1991). However, the review of literature reveal that brand leadership is an important element of brand equity which was also proposed by Aaker (1996), but very limited studies contributed to its measurement. Specifically, previous studies that used brand leadership as a dimension of brand equity in their empirical works are scarce. Based on the gaps mentioned above, this study aims to examine the effects of advertising and country of origin on building brand equity. The automotive industry in Malaysia is selected to fulfill the stated objective. This is because the automotive industry is one of the main drivers of economic development and contributes significantly to socio economic development of the country. The following section reviews the past literature on advertising and country of origin and explains how they may affect brand equity.

\section{LITERATURE REVIEW}

\subsection{Brand equity}

Brand equity is one of the foremost established concepts in the field of branding that has been discussed by a number of researchers and business practitioners. The main reason for this popularity refers to the strategic importance of brand equity in enabling the management to take better decisions that could help them to obtain sustainable competitive advantage and retaining customers (Ardestani et al., 2014). Brand Equity was defined by Aaker (1991) as "a set of assets and liabilities linked to a brand, its name and symbol that add to or subtract from the value provided by a product or service to a firm and/or that firm's customers". This means that brand equity is associated with intangible values that customers associate with a brand. Keller (1993) described brand equity as the differential impact of brand knowledge on the responses of customers to different marketing activities.

Brand equity concept has been discussed thoroughly in different sources of literature, and it appears that there is no definite definition towards this concept due to the differences in measuring it. Evidently, there are two approaches to measure brand equity, namely customer based and the 
financial perspective. Simon and Sullivan (1993) noted that brand equity can be evaluated based on the financial value of the brand to the organization, whereas Aaker (1991) and Keller (2008) established that brand equity denotes the value endowed by a brand to its customers. The financial perspective indicates that brand equity can be evaluated according to financial gains and profits. On the other hand, customer-perspective refers to the intangible values provided by a brand to its customers. However, this study focuses on customer-perspective; this is because customers are the main source of profits and greater revenues.

Previous literatures reveal that different scholars used different dimensions to measure brand equity. The most established measures to test brand equity were suggested by Aaker (1991) and obtained the highest attention from several researchers. The dimensions include: perceived quality, brand awareness, brand association, and brand loyalty. Further contribution to brand equity theory was provided by Keller (1993) who indicated that it can be measured according to brand awareness and brand image. Moreover, Shocker and Weitz (1988) established brand loyalty and brand image as the key components of brand equity. Aaker (1996) included brand leadership as a key dimension of brand equity. Likewise, Yoo and Donthu (2001) asserted that brand equity can be evaluated according to the four dimensions that were proposed by Aaker (1991). However, this study intends to make a contribution to brand equity theory by using four unique dimensions to measure it; brand awareness, brand image, brand loyalty, and brand leadership.

Brand awareness as described by Keller (1993) refers to the ability of customers to remember or recall a brand when they have intentions to buy particular products or services. It measures the extent to which customers are aware about the availability and existence of a brand. Brand loyalty on the other hand refers to the willingness of customer to purchase the same brand repeatedly without any intention to switch to others (Hameed, 2013). Achieving customer loyalty to a brand provides several advantages, such as cost reduction, higher commercial power, protecting customers from switching to other competitors, and greater profitability (Haghighi et al., 2013). Moreover, brand image refers to customers' overall impressions and perceptions of a brand and is positively related with customer satisfaction (Porter \& Claycomb, 1997). Finally, brand leadership reflects the capability of a brand to differentiate itself through innovation and quality of product offerings (Aaker, 1996). Brands acquiring leadership positions are more popular and widely accepted. In the following section, advertising and country of origin as key success factors to build sustainable brand equity are discussed.

\subsection{Advertising}

Advertising is one of the most important elements of marketing communication that is used to capture the attention of customers and persuade them to buy certain products and services of a brand. It was expressed by Belch and Belch (2003); Cengiz et al. (2007) as any paid form of non-personal communication about a brand, its products and services, or any idea that is sponsored by a number of stakeholders attempting to persuade and influence customers to form favourable purchase decisions. Agrawal (1996) illustrated that advertising can be used as a defensive strategy to create brand loyalty, which could help firms to maintain loyal consumers. According to Moorthy and Hawkins (2005), advertising plays an important role in strengthening business performance and developing positive usage experience of a certain brand. Similarly, Kotler (2002) reported that the main purpose of advertising is to improve customers' responses to the brand and its offerings. Therefore, advertising plays an important role in influencing consumers' purchase decisions.

Shimp (2007) indicated that several organizations believe in the strength of advertising as it has various key communications attributes which include informing, reminding and increasing salience, adding value, influencing, and assisting other firm's efforts. Moreover, effective advertising could affect the perception of product quality and other features related to a product, thereby leading to improved market share and better profitability (Light \& Morgan, 1994). Clark et al. (2009) demonstrated that advertising could be considered as a powerful tool in affecting the brand and the utility that derives from it. Thus, brands that advertise more frequently are usually rewarded by high 
stock returns and better performance (Raithel et al., 2011). In addition, advertising is an important informational tool used to inform customers about the critical features of a product or service and acts as a signal of quality.

The main goal of advertising as a key promotional strategy is to obtain positive responses from the targeted customers. Mogire and Oloko (2014) established that there are several tools of advertising to communicate a brand such as: television and radio advertisements; direct mail where it is possible to send marketing information directly to customers; print advertisements in the form of newspapers, journals, and magazines; and outdoor advertising which include posters, bus ads, signs, and banners. Similarly, Hameed (2013) considered radio, newspapers, and television as the most traditional methods of advertising to build brand image and help firms to generate higher sales and revenues. Mutsikiwa et al. (2013) also suggested different means to advertise a brand, and this includes event sponsorship, trade shows, radio, cell phone and internet, billboards, television, posters, kiosks, newspapers, and magazines.

Previous literature indicated that advertising in all of its forms represents a vehicle to build sustainable brand equity. For instance, Ardestani et al. (2014) found that advertising had significant positive influence on brand awareness, brand loyalty, and brand image. Morden (1991) considered advertising as a powerful tool to build brand awareness about products or services in the minds of customers, and to create better knowledge about it. Certain scholars also confirmed that advertising had significant positive impact on brand awareness and loyalty (Agrawal, 1996; Ha et al., 2011; Hameed, 2013; Mutsikiwa et al., 2013). Additionally, Neiderhauser (2013) regarded successful advertisement as the main driver of brand image and brand leadership. Based on the discussion made above, the following hypotheses are proposed:

H1: Advertising has positive effect on brand awareness.

$\mathrm{H} 2$ : Advertising has positive effect on brand loyalty.

H3: Advertising has positive effect on brand image.

H4: Advertising has positive effect on brand leadership.

H5: Advertising has positive effect on overall brand equity.

\subsection{Country of origin}

Previous literature established country of origin as one of the key factors that significantly affected the purchase decisions of customers. It was defined by Saydan (2013) as the perceptions of customers towards products or services of a particular country through the belief, impressions or ideas that could influence their purchase decisions. Rezvani et al. (2012) thought about country of origin as the country where the headquarter of the company is located. Similarly, Roth and Romeo (1992) expressed country of origin image as the customers' overall perceptions about products from a certain country based on their perceptions of production and marketing strengths or weaknesses of brands from that country. Therefore, country of origin image refers to the stereotype impressions that customers develop toward brands originating from a certain country through the evaluation of product or service quality. Particularly, consumers hold certain images about a particular country, which can affect their evaluations of brands originating from that country (Hilman \& Hanaysha, 2015; Shahin et al., 2012).

Country of origin plays a significant role in influencing consumer behaviour in competitive markets as the stereotypes of a country affect the purchase intention. For instance, Martin and Eroglu (1993) indicated that customers develop certain impressions about country of origin according to several aspects that include economical, social, political, and technology. Teo et al., (2011) considered political system, economy, and culture of the country as sensitive aspects to customers. Some researchers also believed that country image is associated with product characteristics and past experience (Rezvani et al., 2012). In general, consumers are more conscious about the quality of products and tend to link it to country of origin (Parkvithee \& Miranda, 2012). In addition, country or 
origin plays a critical role in consumers' evaluation of brands (Koubaa, 2008) and purchase decisions on account of product quality, word of mouth communication, and past experience.

Roth and Romeo (1992) demonstrated that a country's image can be evaluated through several aspects that indicate the quality of production profile. Such aspects include innovation through technology, product design, prestige, and workmanship. However, when customers are not familiar about a brand or certain products, they tend to use country of origin as an extrinsic cue to evaluate the quality and performance, because they are difficult to be copied or imitated (Johansson \& Nebenzahl, 1986). In fact, customers prefer to purchase products or services of particular brands that are made in countries associated with favourable images (Shahrokh \& Azodi, 2013). Fournier (1998) declared that country of origin relates a product to its original national identity, which would ultimately result in a strong emotional attachment to brands and products originating from that country.

Country of origin is highly regarded as an important factor that influences customer's perceptions of brands (Kim, 1995) and it could appear as an extrinsic cue of brand association that drives brand equity (Shahin et al., 2012). In past studies, it was found that country of origin had positive impact on brand equity (Lee et al., 2014; Saydan, 2013; Yasin at al., 2007). Ayyildiz and Cengiz (2007) revealed that country of origin affects the loyalty of customers towards brands originating from a certain country. Similarly, Shahin et al. (2012) found that country of origin has a significant positive impact on brand awareness, brand loyalty, and brand image. They indicated that countries with favourable images are usually familiar to the customers and perceived as manufactures of quality brands. Such brands have the ability to differentiate themselves from others and have high popularity. Other scholars such as Hsieh et al. (2004); and Cervino et al. (2005) reported that country of origin had positive impact on brand image. Moreover, positive country of origin image can assist business managers to build global brand leadership (Aaker \& Joachimsthaler, 2000). Based on the discussion made above, the following hypotheses are presented:

H6: Country of origin has positive effect on brand awareness.

H7: Country of origin has positive effect on brand loyalty.

H8: Country of origin has positive effect on brand image.

H9: Country of origin has positive effect on brand leadership.

H10: Country of origin has positive effect on overall brand equity

\section{METHODOLOGY}

This study was designed to test the effects of advertising and country of origin on building brand equity in the automotive industry of Malaysia in Northern area. According to the official portal of road and transport department, there are more than one million registered passenger cars on road in Northern Malaysia. This means that the population of this study was more than one million. Therefore, following the recommendation of Krejcie and Morgan (1970), 384 questionnaires were distributed on the respondents to ensure the representation of sample size. Data was collected from passenger car owners at shopping malls. The systematic sampling method was employed in order to ensure the randomness of data collection. To do so, every $10^{\text {th }}$ leaving customer was approached at the exit spots of selected shopping malls. In total, 287 questionnaires were returned back from the respondents.

The measurement scales of constructs were taken from previous researches. Particularly, five items were taken from the study of Yasin et al. (2007) to measure country of origin. To measure advertising, seven items were taken from Yoo and Donthu (2001) to ensure they are fit to the context of the present study. Moreover, brand equity which in composed of four dimensions (brand awareness, brand image, brand loyalty, and brand leadership) was measured based on a number of items for each dimension which were also taken from previous studies. A 3-items scale of brand awareness was taken from Yoo et al. (2000). Similarly, 5-items scale to measure brand image was taken from the study of Nigam and Kaushik (2011). Moreover, the measurement scale of brand 
loyalty was taken from Nigam and Kaushik (2011). Finally, brand leadership was measured using five items scale which was adapted from Aaker (1996); Liaogang et al. (2007). All of the designed measurements were measured on a seven-Point Likert scale ranging from strongly disagree (1) to strongly agree (7).

The collected data were at first analyzed using SPSS 19 to test respondents' profile, generate Cronbach's alpha values, and to replace the missing values. Then the final data were analyzed using structural equation modeling on AMOS 18. In particular, confirmatory factor analysis (CFA) was calculated based on the measurement model. After ensuring the acceptable factor loading, the data were transferred to structural model for further analyses and to test the hypotheses. From regression table, it was possible to identify the significant results of hypotheses. The following section presents the findings of this study with some interpretations for the ease of understanding. Then, the discussion on the results and final conclusion are highlighted.

\section{ANALYSES OF RESULTS}

The analysis of demographic profile of the sample indicated that $136(47.4 \%)$ of the respondents are male, whereas $151(52.6 \%)$ are female. Furthermore, $12.5 \%$ of the respondents were 25 years old or less, while $48.8 \%$ represented the age group of 26 to 35 . Those whose ages between 36 and 45 had accounted for $16 \%$ of the study, while $22.6 \%$ represented the age group of 46 and more. The results also illustrated that most of the respondents $(75.3 \%)$ were Muslims, $4.5 \%$ were Hindu, $4.9 \%$ were Christians, $14.6 \%$ were Buddhists, and only $0.7 \%$ belong to other religions.

To ensure construct validity, confirmatory factor analysis was conducted using AMOS to determine the values of factor loadings on items. Specifically, items with low values of factor loadings (less than 0.5 ) were deleted. The findings revealed that six items were deleted because some of them had factor loadings with values less than 0.5 . The deletion was also done in order to ensure the goodness of model fit. Moreover, the reliability test was conducted on all constructs to determine their internal consistency and fulfill the assumptions of convergent validity. In general, the results revealed that all of the constructs had acceptable reliability with Cronbach's alpha of more than 0.70 . The details are shown in Appendix A.

After achieving good fit for the measurement model, a structural model was then drawn to estimate the direct effects of advertising and country of origin on brand equity and its dimensions; brand awareness, brand image, brand loyalty, and brand leadership. As shown in Figure 1, the proposed model fits the data well according to various indices. In particular, the value of chi-square ( $\mathrm{x} 2)$ is equal to 541.180. Other fit $(\mathrm{df}=222, \mathrm{GFI}=0.841$, AGFI $=0.802$, TLI $=0.942, \mathrm{CFI}=949$, and RMSEA $=0.075$ ) were also used to confirm the appropriateness of data to the model and achieve good fit. According to these results, it can be suggested that the current model has produced a good fit to the data. 


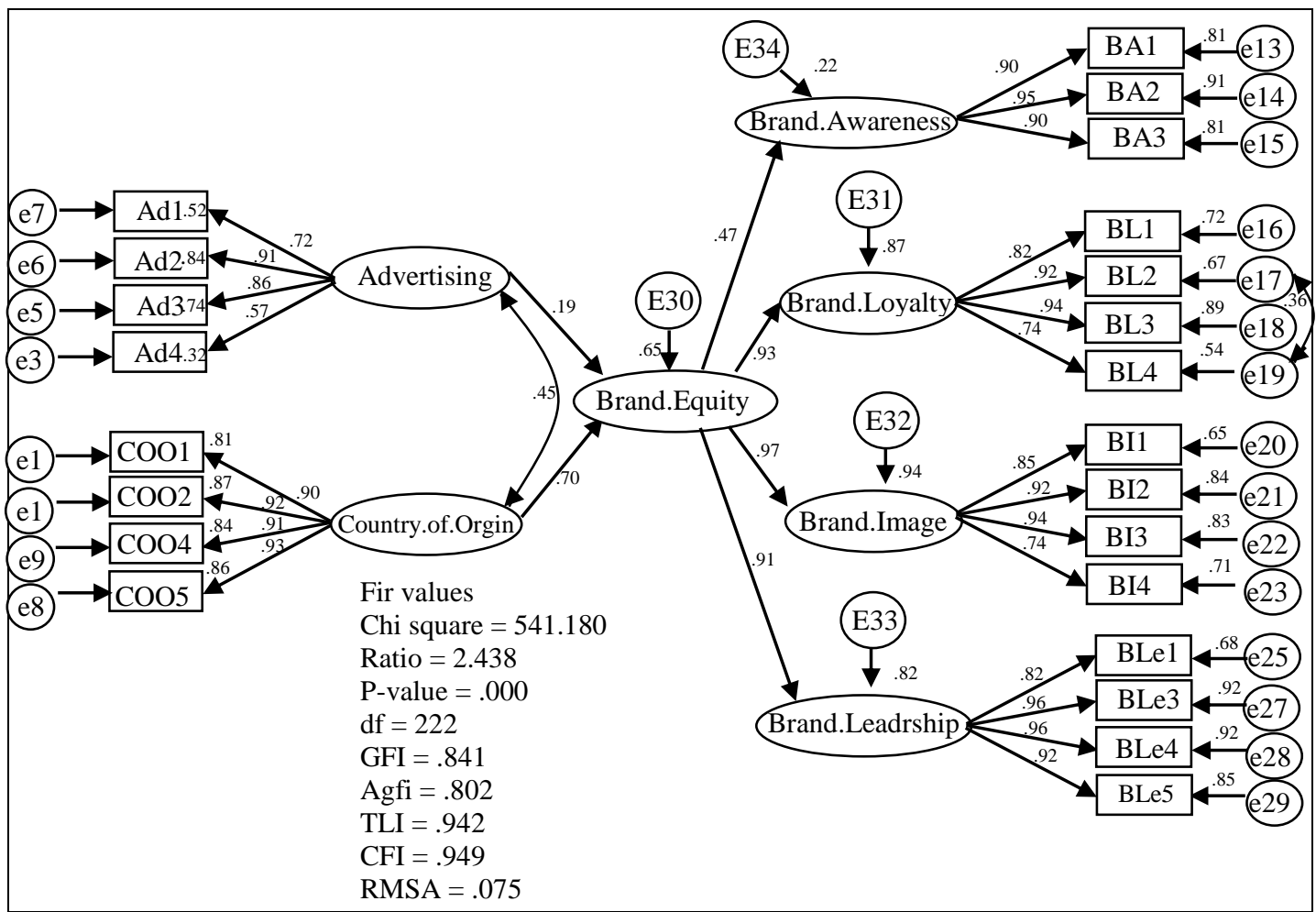

\section{Figure 1: Structural model}

In order to test the results of hypotheses, the regression table based on structural model estimates was then generated. As shown in Table 1, all of the hypotheses are supported. As HI stated that advertising has positive effect on brand awareness, the results support this hypothesis $(\beta=0.187$, $t-$ value $=2.607, \mathrm{p}<0.05)$ and it is statistically significant. Similarly, $\mathrm{H} 2$ which states that advertising has positive effect on brand loyalty was also statistically supported $(\beta=0.193$, $t$-value $=3.485$, $\mathrm{p}<0.05)$. Moreover, the findings revealed that advertising has significant positive impact on brand image $(\beta=0.197, \mathrm{t}$-value $=3.734, \mathrm{p}<0.05)$, thus, $\mathrm{H} 3$ is accepted. With regard to the effect of advertising on brand leadership, the result is statistically significant and positive $(\beta=0.147$, t-value $=3.066, \mathrm{p}<0.05)$, hence, $\mathrm{H} 4$ is confirmed. In general, the findings reveal that advertising has significant positive impact on overall brand equity $(\beta=0.186$, $t$-value $=3.271, p<0.05)$, therefore, H5 is accepted.

The findings also indicated that country of origin has significant positive impact on brand awareness $(\beta=0.328$, $t$-value $=4.709, p<0.05)$, thus, H6 is accepted. It ws also found that country of origin has significant positive impact on brand loyalty $(\beta=0.677$, $t$-value $=11.368, p<0.05)$, which means that $\mathrm{H} 7$ is also supported. The findings further revealed that country of origin has significant positive impact on brand image $(\beta=0.700$, t-value $=11.674, \mathrm{p}<0.05)$, thus, H8 is accepted. With regard to the effect of country of origin on brand leadership, the result is statistically significant and positive $(\beta=0.753$, t-value $=12.791, \mathrm{p}<0.05)$, hence, H9 is confirmed. Finally, the results showed that country of origin has significant positive impact on overall brand equity $(\beta=0.703$, t-value $=6.741$, $\mathrm{p}<0.05$ ), therefore, H10 is accepted.

Table 1: Results of hypotheses

\begin{tabular}{lcccc}
\hline Hypothesis & $\begin{array}{c}\text { Std. } \\
\text { Estimate }\end{array}$ & t-value & P & Decision \\
\hline $\mathrm{H} 1:$ Advertising $\rightarrow$ Brand awareness & 0.187 & 2.607 & 0.009 & Supported \\
$\mathrm{H} 2:$ Advertising $\rightarrow$ Brand loyalty & 0.193 & 3.485 & $* * *$ & Supported \\
\hline
\end{tabular}




\begin{tabular}{lcccc}
\hline H3: Advertising $\rightarrow$ Brand image & 0.197 & 3.734 & $* * *$ & Supported \\
H4: Advertising $\rightarrow$ Brand leadership & 0.147 & 3.066 & 0.002 & Supported \\
H5: Advertising $\rightarrow$ Overall brand equity & 0.186 & 3.271 & 0.001 & Supported \\
H6: Country of Origin $\rightarrow$ Brand awareness & 0.328 & 4.709 & $* * *$ & Supported \\
H7: Country of Origin $\rightarrow$ Brand loyalty & 0.677 & 11.368 & $* * *$ & Supported \\
H8: Country of Origin $\rightarrow$ Brand image & 0.700 & 11.674 & $* * *$ & Supported \\
H9: Country of Origin $\rightarrow$ Brand leadership & 0.753 & 12.791 & $* * *$ & Supported \\
H10: Country of Origin $\rightarrow$ Overall brand equity & 0.703 & 6.741 & $* * *$ & Supported \\
\hline
\end{tabular}

\section{DISCUSSION AND CONCLUSION}

The main objective of this study was to test the impact of advertising and country of origin on brand equity to bring empirical evidence from automotive sector. In general, the findings support the positive effect of these factors on building brand equity and its elements. More specifically, it is found that advertising has a significant positive influence on brand awareness. In other words, more advertising spending increases brand awareness. Such finding confirms the importance of advertising programs in increasing the awareness of customers, particularly, during the stages of introduction of new products and service which can create certain ideas in consumers' mind about the brand. Moreover, Piratheepan and Pushpanathan (2013) confirmed that advertising positively affected brand awareness. This study also showed that advertising has significant positive influence on brand loyalty, and it matches with certain past researches (Ardestani et al., 2014; Ramiz et al., 2014).

The results of this paper also provide empirical evidence that advertising has significant and positive impact on brand image. The finding was supported by certain previous researches (Durrani et al., 2015; Ramiz et al., 2014). Similarly, the findings of this study demonstrated that advertising has significant positive influence on brand leadership. This means that higher emphasis on advertising can help organizations to enhance their popularity and brand competitiveness. In general, this study found that advertising has significant positive impact on overall brand equity. The result is in line with previous researches which found that advertising was positively related to brand equity (Jedidi et al., 1999; Makasi et al., 2014; Selvakumar \& Vikkraman, 2013). Therefore, by focusing on advertising, firms could have better chances to gain sustainable competitive advantage and obtain sustainable brand equity.

Moreover, this study provides empirical evidence that country of origin has significant positive impact on brand equity and it was supported by past studies (Liu, 2012; Norouzi \& Hosienabadi, 2011; Saydan, 2013). In particular, country of origin has significant positive influence on brand awareness and the finding was supported by Norouzi and Hosienabadi (2011). The impact of country of origin on brand loyalty was also confirmed. The finding is in line with previous studies (Azuizkulov, 2013; Shahrokh \& Azodi, 2013). This means that brand loyalty is highly associated with country of origin, particularly, in the case of automotive products. The findings also established that country of origin has positive impact on brand image and it was supported by previous researches (Koubaa, 2008). The positive effect on brand image indicates that country of origin plays an important role in affecting the perceptions of customer and their overall evaluation toward a brand. Finally, the findings of this paper indicated that country-of-origin has positive impact on brand leadership. Therefore, positive perceptions of country image should increase the attraction of customers to purchase the products and services and create barriers to competitive threats. This as a result could result in sustainable brand equity and higher performance.

This study has some limitations that can be considered in future researches. First, the data was collected from a sample of respondents in northern area of Malaysia, therefore, future research is recommended to test the variables in different contexts with larger sample sizes. Second, this study examined only two antecedents of brand equity; advertising and country of origin. Therefore, future studies should focus on other variables such as price deals and service quality. Additionally, this paper relied on primary data to examine the hypotheses; hence, future research may employ in-depth 
interviews and use case studies to gain better understanding on how to build sustainable brand equity. Finally, brand leadership was suggested by Aaker (1996) as a key element of brand equity, buy only few studies contributed to measuring this dimension. Thus, future research is suggested to use brand leadership as a key measure of brand equity.

In conclusion, this study builds upon the importance of advertising and country of origin as key success factors in building sustainable brand equity. It suggests for automotive manufacturers to put further emphasis on such factors when designing their branding strategies for the purpose of building their global competiveness. Generally, this study indicates that being capable to utilize creative advertising methods that would be attractive to customers may influence their preferences and purchase decisions. The results also suggest that automotive manufacturers can utilize the name of positive country image to build positive brand image and obtain favourable customer responses. As country of origin has become a cue that can be used by customers to evaluate a brand before purchasing, it is necessary to advertise the positive name to build sustainable brand equity.

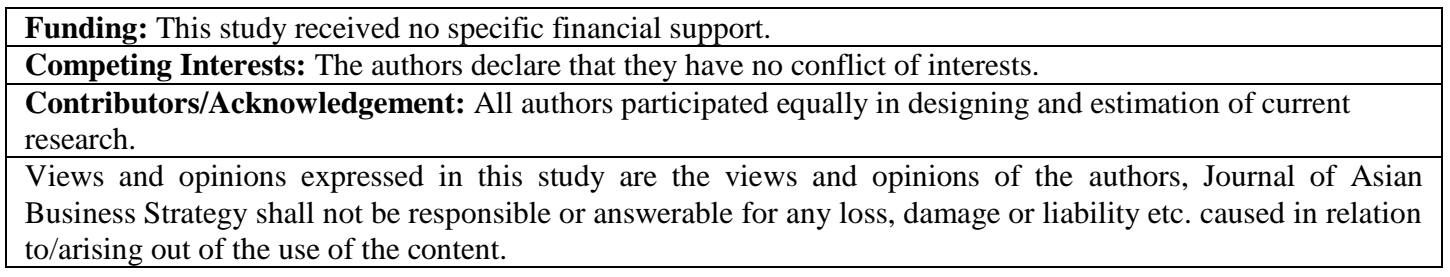

\section{References}

Aaker, D. (1991). Managing brand equity: Capitalizing on the value of a brand name. Free Press: New York.

Aaker, D. A., \& Joachimsthaler, E. (2000). Brand leadership. New York, NY: The Free Press.

Aaker, D. A. (1996). Measuring brand equity across products and markets. California Management Review, 38(3), 102-120.

Agrawal, D. (1996). Effect of brand loyalty on advertising and trade promotions: A game theoretic analysis with empirical evidence. Marketing Science, 15(1), 86-108.

Ardestani, A. S., Mirabi, V. R., Kazemi, M. A. A., \& Far, B. E. (2014). A study on the effect of marketing advertisements and price promotions to brand equity in Iranian insurance industry (a case study on Iran, Asia and Persian insurance companies). Research Journal of Recent Sciences, 3(7), 123-129.

Ayyildiz, H., \& Cengiz, E. (2007). Country image effect on customer loyalty model. Innovative Marketing, 3(2), 42-60.

Azuizkulov, D. (2013). Country of origin and brand loyalty on cosmetic products among Universiti Utara Malaysia students. Atlantic Review of Economics: Revista Atlántica de Economía, 2(1), 139.

Belch, G. E., \& Belch, M. A. (2003). Advertising and promotion (6 ${ }^{\text {th }}$ edition). NY: McGraw-Hell Irwin.

Bennett, P. D. (1995). Dictionary of marketing terms. American Marketing Association, Chicago, IL.

Bilkey, W. J., \& Nes, E. (1982). Country-of-origin effects on product evaluations. Journal Of International Business Studies, 13(1), 89-100.

Cervino, J., Sanchez, J., \& Cubillo, J. M. (2005). Made in effect, competitive marketing strategy and brand performance: An empirical analysis for Spanish brands. Journal of American Academy of Business, 6(2), 237-243.

Cengiz, E., Ayyildiz, H., \& Bünyamin, E. (2007). Effects of image and advertising efficiency on customer loyalty and antecedents of loyalty: Turkish banks sample. Banks and Bank Systems, 2(1), 56-71.

Clark, C. R., Doraszelski, U., \& Draganska, M. (2009). The effect of advertising on brand awareness and perceived quality: An empirical investigation using panel data. $Q M E, 7(2), 207-236$. 
Durrani, B. A., Godil, D. I., Baig, M. U., \& Sajid, S. (2015). Impact of brand image on buying behaviour among teenagers. European Scientific Journal, 11(5), 155-168.

Fournier, S. (1998). Consumers and their brands: Developing relationship theory in consumer research. Journal of Consumer Research, 24(4), 343-353.

Ha, H. Y., John, J., Janda, S., \& Muthaly, S. (2011). The effects of advertising spending on brand loyalty in services. European Journal of Marketing, 45(4), 673-691.

Haghighi, M., Afrasiabi, N., \& Moetamedzadeh, H. R. (2013). Analysis and prediction of how advertisement influences brand equity using new methods of artificial intelligence: A case study on branches of Pasargad Bank in Tehran, Iran. Global Journal of Science, Engineering and Technology, 5, 134-141.

Hameed, F. (2013). The effect of advertising spending on brand loyalty mediated by store image, perceived quality and customer satisfaction: A case of hypermarkets. Asian Journal of Business Management, 5(1), 181-192.

Hankinson, G., \& Cowking, P. (1996). The reality of global brands: Cases and strategies for successful management of international brands. McGraw-Hill, Maidenhead.

Hilman, H., \& Hanaysha, J. (2015). The impact of country of origin on relationship quality: Empirical evidence from automotive industry. Mediterranean Journal of Social Sciences, 6(2), 165-147.

Hsieh, M. H., Pan, S. L., \& Setiono, R. (2004). Product-, corporate-, and country-image dimensions and purchase behavior: A multicounty analysis. Academy of Marketing Science, 32(3), 251-270.

Jedidi, K., Mela, C. F., \& Gupta, S. (1999). Managing advertising and promotion for long-run profitability. Marketing Science, 18(1), 1-22.

Johansson, J. K., \& Nebenzahl, I. D. (1986). Multinational production: Effect on brand value. Journal of International Business Studies, 17(3), 101-126.

Keller, K. L. (1993). Conceptualizing, measuring, and managing customer-based brand equity. Journal of Marketing, 57, 1-22.

Keller, K. L. (2003). Strategic brand management: Building, measuring and managing brand equity. Pearson Education, Upper Saddle River, NJ.

Keller, K. L. (2008). Strategic branding management: Building, measuring and managing brand equity (3rd edition). NJ: Prentice Hall.

Kim, C. K. (1995). Brand popularity and country image in global competition: Managerial implications. Journal of Product and Brand Management, 4(5), 21-33.

Kotler, P. (2002). Marketing management: Millennium edition. New Jersey, Pearson Education Ltd.

Koubaa, Y. (2008). Country of origin, brand image perception, and brand image structure. Asia Pacific Journal of Marketing and Logistics, 20(2), 139-155.

Krejcie, R. V., \& Morgan, D. W. (1970). Determining sample size for research activities. Educational and Psychological Measurement, 30, 607-610.

Lee, H. M., Chen, T., \& Guy, B. S. (2014). How the Country-of-Origin Image and Brand Name Redeployment Strategies Affect Acquirers' Brand Equity After a Merger and Acquisition. Journal of Global Marketing, 27(3), 191-206.

Liaogang, H., Chongyan, G., \& Zi'an, L. (2007). Customer-based brand equity and improvement strategy for mobile phone brands: Foreign versus local in the Chinese market. International Management Review, 3(3), 76-83.

Light, L. \& Morgan, R. (1994). The fourth wave: brand loyalty marketing New York: Coalition for brand equity. American Association of Advertising Agencies.

Liu, Y. (2012). Country of origin and customer-based brand equity: A quantitative study on Chinese cars going global. Master thesis, Aalto University.

Makasi, A., Govender, K., \& Rukweza, C. (2014). Building brand equity through advertising. Mediterranean Journal of Social Sciences, 5(20), 2613-2624.

Martin, I. M., \& Eroglu, S. (1993). Measuring a multi-dimensional construct: country image. Journal of business research, 28(3), 191-210.

Mogire, V. B., \& Oloko, M. (2014). Advertising promotion strategy and brand equity: A comparative study of Ariel and omo washing powders, Nairobi - Kenya. International Journal of Management and Commerce Innovations, 2(1), 22-29. 
Moorthy, S., \& Hawkins, S. A. (2005). Advertising repetition and quality perception. Journal of Business Research, 58, 354- 360.

Morden, A. R. (1993). Elements of marketing. London: DP Publications.

Mutsikiwa, M., Dhliwayo, K., \& Basera, C. H. (2013). The impact of advertising on building brand equity: A case of Zimbabwean universities. European Journal of Business and Management, 5(9), 197-210.

Neiderhauser, J. E. (2013). How Nike's leadership affects brand image internally and externally. $U W$ L Journal of Undergraduate Research, 16, 1-10.

Nigam, A., \& Kaushik, R. (2011). Impact of brand equity on customer purchase decisions: An empirical investigation with special reference to hatchback car owners in central Haryana. International Journal of Computational Engineering \& Management, 12, 121-128.

Norouzi, A., \& Hosienabadi, B. F. (2011). The effects of brand's country-of-origin image on the formation of brand equity. Australian Journal of Basic \& Applied Sciences, 5(12), 766-770.

Parkvithee, N., \& Miranda, M. J. (2012). The interaction effect of country-of-origin, brand equity and purchase involvement on consumer purchase intentions of clothing labels. Asia Pacific Journal of Marketing and Logistics, 24(1), 7-22.

Piratheepan, U., \& Pushpanathan, A. (2013). Impact of promotional strategies on brand awareness: A study on milk powder brands in Nuwaraeliya district. IFRSA Business Review, 3(4), 268-272.

Porter, S. S., \& Claycomb, C. (1997). The influence of brand recognition on retail store image. Journal of Product and Brand Management, 6(6), 373-387.

Raithel, S., Scharf, S., Taylor, C. R., Schwaiger, M., \& Zimmermann, L. (2011). Marketing accountability: Applying data envelopment analysis to assess the impact of advertising efficiency on shareholder value. Advances in International Marketing, 22(1), 115-39.

Ramiz, M., Qasim, M., Rizwan, M., Aslam, F., \& Khurshid, A. (2014). The comparative analysis of the factors effecting brand loyalty towards samsung products. Journal of Sociological Research, 5(1), 327-349.

Rezvani, S., Dehkordi, G. J., Rahman, M. S., Fouladivanda, F., Habibi, M., \& Eghtebasi, S. (2012). A conceptual study on the country of origin effect on consumer purchase intention. Asian Social Science, 8(12), 205-215.

Roth, M. S., \& Romeo, J. B. (1992). Matching product category and country image perceptions: a framework for managing country of origin effects. Journal of International Business studies, 23(3), 477-97.

Saydan, R. (2013). Relationship between country of origin image and brand equity: An empirical evidence in England market. International Journal of Business and Social Science, 4(3), 78-88.

Selvakumar, J. J., \& Vikkraman, P. (2013). Impact of advertising and price promotions on brand equity in service sector. Journal of Contemporary Research in Management, 6(3), 51-65.

Shahin, A., Kazemi, A., \& Mahyari, H. K. (2012). How consumer's perception of country of origin affects brand equity: A case study in Iran. Middle-East Journal of Scientific Research, 12(6), 878-885.

Shahrokh, Z. D., \& Azodi, A. D. (2013). The effect of country of origin image on brand equity and purchase intention. Journal of Applied Environmental and Biological Sciences, 3(12), 52-61.

Shimp, A. T. (2007). Advertising, promotion, and other aspects of integrated marketing communications $\left(7^{\text {th }}\right.$ Edition). Natorp Boulevard Mason, Thomson Higher Education.

Shocker, A. D., \& Weitz, B. (1988). A perspective on brand equity principles and issues. Report, (88104). MA: Marketing Science Institute, Cambridge, 2-4.

Simon, C. J., \& Sullivan, M. W. (1993). The measurement and determinants of brand equity: A financial approach. Marketing Science, 12(1), 28-53.

Takali, H., Hamidi, M., Khabiri, M., Sajjadi, N., \& Alhani, F. (2012). The analysis of experts' perceived experience of the effective factors in brand equity of Iranian national Olympic committee. World, 6(4), 441-451.

Teo, P. C., Mohamad, O., \& Ramayah, T. (2011). Testing the dimensionality of Consumer Ethnocentrism Scale (CETSCALE) among a young Malaysian consumer market segment. African Journal of Business Management, 5(7), 2805-2816. 
Yasin, N. M., Noor, M. N., \& Mohamad, O. (2007). Does image of country-of-origin matter to brand equity? Journal of Product \& Brand Management, 16(1), 38-48.

Yoo, B., \& Donthu, N. (2001). Developing and validating multidimensional consumer-based brand equity scale. Journal of Business Research, 52(1), 1-14.

Yoo, B., Donthu, N. \& Lee, S. (2000). An examination of selected marketing mix elements and brand equity. Academy of Marketing Science, 28(2), 195-212.

\section{Appendix A: Measurement scale of constructs}

\begin{tabular}{llc} 
Code & Advertising $(\boldsymbol{\alpha}=\mathbf{0 . 8 3 3})$ & $\begin{array}{c}\text { Factor } \\
\text { loadings }\end{array}$ \\
\hline Ad1 & I think the advertising of this car brand is in general attractive. & 0.723 \\
Ad2 & I like the advertising campaigns for this car brand. & 0.914 \\
Ad3 & $\begin{array}{l}\text { My opinion about this car brand's advertising is effective. } \\
\text { Ad5 }\end{array}$ & 0.859 \\
This car brand is widely advertised compared to other competing brands & 0.566 \\
COO1 & $\begin{array}{l}\text { This car brand originated from a country high in R\&D compared to other brands. } \\
\text { COO2 }\end{array}$ & $\begin{array}{l}\text { This car brand originated from a country with a high level of technological } \\
\text { advancement compared to other brands. }\end{array}$ \\
COO4 & $\begin{array}{l}\text { This car brand originated from a country which maintains an image of continuous } \\
\text { car development compared to other brands. }\end{array}$ & 0.899 \\
COO5 & $\begin{array}{l}\text { This brand originated from a country which is prestigious in terms of car } \\
\text { manufacturing compared to other brands. }\end{array}$ & 0.914 \\
\hline
\end{tabular}

\section{Brand equity}

\begin{tabular}{llc}
\hline & a. Brand awareness $(\boldsymbol{\alpha}=\mathbf{0 . 9 4 1})$ & $\begin{array}{c}\text { Factor } \\
\text { loadings }\end{array}$ \\
\hline BA1 & I know how the symbol of this car brand looks like. & 0.901 \\
BA2 & I can recognize the brand of this car among other competing brands. & 0.952 \\
BA3 & I can quickly recall the symbol or logo of this car brand. & 0.902 \\
BL1 & b. Brand loyalty ( $\boldsymbol{\alpha}=\mathbf{0 . 9 1 4})$ & 0.851 \\
BL2 & If in future, I want to buy a new car this brand would be my first & 0.818 \\
BL3 & choice. & 0.943 \\
BL4 & I will recommend thill car brand this car brand even if it increases the price. & 0.735 \\
BI1 & c. Brand image ( $\boldsymbol{\alpha}=\mathbf{0 . 9 2 5})$ & 0.808 \\
BI2 & This car brand has created a distinct image in my mind. & 0.916 \\
BI3 & This car brand has given me whatever it promised to me. & 0.909 \\
BI4 & This car brand I'm using is associated with the manufacturer's image. & 0.845 \\
BLe1 & d. Brand leadership $(\boldsymbol{\alpha}=\mathbf{0 . 9 5 2})$ & 0.822 \\
BLe3 & This car brand is one of the leading brands in its category. \\
BLe4 & This car brand is innovative, first with advances in services. \\
BLe5 & This car brand is stylish when it comes to product design. & 0.958 \\
\hline
\end{tabular}

